\title{
BAX G(-248)A Gene Polymorphism and Its Association with Risk of Non-Small Cell Lung Cancer-A Case Control Study
}

\author{
Jamsheed Javid1, Rashid Mir², Pramod Kumar Julka³, Prakash Chandra Ray, \\ Alpana Saxena ${ }^{{ }^{*}}$ \\ ${ }^{1}$ Department of Biochemistry, Maulana Azad Medical College and Associated Hospitals, New Delhi, India \\ ${ }^{2}$ Prince Fahd Bin Sultan Research Chair, Faculty of Applied Medical Sciences, University of Tabuk, Tabuk, Saudia \\ Arabia \\ ${ }^{3}$ Department of Radiotherapy and Oncology, All India Institute of Medical Sciences, New Delhi, India \\ Email: rashidaiims@gmail.com
}

Received 9 February 2015; accepted 26 April 2015; published 29 April 2015

Copyright (C) 2015 by authors and Scientific Research Publishing Inc.

This work is licensed under the Creative Commons Attribution International License (CC BY).

http://creativecommons.org/licenses/by/4.0/

c) (i) Open Access

\begin{abstract}
Pro-apoptotic Bcl-2 protein BAX is an important member of mitochondrial dependent apoptosis regulation and ultimately plays a pivotal role in malignancies. A promoter $G(-248) A$ polymorphism in the TP53 binding region of BAX results in differential binding capacity of TP53 protein there by regulating its expression, which has been found to be associated with different clinical outcomes in various malignancies. Presently we aimed to analyze the possible impact of the BAX G(-248)A polymorphism on the risk and other clinical features of non-small cell lung cancer in Indian population. The BAX promoter polymorphism was analyzed in blood samples of 320 subjects with 1:1 case/control ratio by primer-introduced restriction analysis PCR and survival curves were plotted using Kaplan-Meier analysis. It was observed that more than 3 -fold increased risk of developing non-small cell lung cancer was associated with homozygous AA genotype of BAX G(-248)A promoter polymorphism in Indian population, with more predominant in smokers with pack-year > 45 (heavy) and using cigarette or huka as their smoking source than homozygous GG genotype. Significant associations was observed between TNM stage $(p=0.037)$ and histological type (0.02), of non-small cell lung cancer patients with the polymorphism. Patients homozygous for A allele exhibited a significant poor overall survival compared with patients displaying GA + AA or GA or GG genotype [median survival 6.0 vs 9.0, 11.0, and 30.0 months, respectively $(p<$ 0.0001)]. Adenocarcinoma and advanced stage patients with AA genotype showed lower median survival time than squamous cell carcinoma and early stage non-small cell lung cancer patients (median 3.0 and 5.0 vs 8.0 and 9.0 months, respectively). We conclude that the genetic polymorphism G(-248)A in the TP53 binding promoter region of pro-apoptotic genes BAX may contribute to the risk of developing non-small cell lung cancer in Indian population and also may be an important factor for adverse clinical outcome for patients with non-small cell lung cancer.
\end{abstract}

*Corresponding author.

How to cite this paper: Javid, J., Mir, R., Julka, P.K., Ray, P.C. and Saxena, A. (2015) BAX G(-248)A Gene Polymorphism and Its Association with Risk of Non-Small Cell Lung Cancer-A Case Control Study. Open Journal of Apoptosis, 4, 47-58. 
Keywords

\section{BAX G(-248)A Polymorphism, PIRA-PCR, NSCLC Risk}

\section{Introduction}

Lung cancer has become one of the most common malignancies worldwide and in India. It is the leading cause of cancer-related deaths [1] [2]. Majority of lung cancer patients are diagnosed as non-small cell type including squamous cell, adenocarcinoma and large cell lung carcinoma as the three major subtypes with 5-year survival rate of 11 to 15 percent overall, and less than 5 percent at stage IIIB/IV [3]. Exposure to smoke and environmental derived pro-carcinogens are the established risk factors for lung cancer wherein smoking accounts for $80 \%$ to $90 \%$ of cases among men and $55 \%$ to $80 \%$ of cases among women [4]. Occupational exposures in industrial facilities account for an additional $9 \%$ to $15 \%$ of lung cancer cases [5]. However, only a small fraction of smokers and workers in high-risk occupations develop this disease. This suggests that other causes, including genetic susceptibility, may contribute to the variation in individual lung cancer risk. Despite the development of new chemotherapeutic drugs and multimodal treatment strategies, the survival rate of non-small cell lung cancer remains unchanged and poor. Identification of new prognostic markers for the characterization of lung cancer biology may be helpful, as they could serve as a basis for predicting response to therapy at a molecular level [6].

Apoptosis also known as programmed cell death is an ordered and orchestrated cellular process that regulates cell death under normal physiological as well as pathological conditions [7]. Apoptosis and cell cycle progression are two intimately linked phenomena and uncontrollable cell proliferation perturbs the cellular homeostasis which may lead to malignancies. The Bcl-2 family of proteins, comprising of pro and anti-apoptotic proteins, plays a pivotal role in the regulation of apoptosis, especially via the intrinsic pathway [8]. One of the important regulators included pro-apoptotic Bcl2 associated X protein (BAX) encoded by BAX gene located on chr 19q13.3 consisting of 6 exons and 5 intervening introns. The BAX gene encodes a $21 \mathrm{kDa}$ protein, named BAX-alpha, which hetero-dimerizes either with members of the BCL2 family of proteins or with tyrosine kinases for its proapoptotic function. Single-nucleotide polymorphism located within the 5' un-translated region of the BAX promoter -248 G/A (rs 4645878), was reported to correlate with reduced BAX expression [9] [10] and was found to be associated with various malignancies [9] [11]-[17]. In the present study, we hypothesized that BAX G(-248)A polymorphism may also be associated with risk and adverse clinical outcome of NSCLC in Indian population.

\section{Materials and Methods}

\subsection{Study Population}

Present study was approved by Institutional ethics committee of Maulana Azad Medical College \& associated hospitals, New Delhi. 160 peripheral blood samples from newly diagnosed as well as therapy received NSCLC patients and gender-age ( \pm 5 years) matched 160 cancer free healthy controls were included. Patients with a history of previous cancer or metastasized cancer from other organs except lung were excluded. Both cases as well as controls belonging to north India. All subjects received a detailed description of this study and provided written informed consent. Patient follow up was obtained through of hospital records as well as by direct patient contact. The distribution of the selected characteristics for those with NSCLC and the controls are summarized in Table 1. Tumor stage and grade of NSCLC patients were determined using $7^{\text {th }}$ edition of the Lung cancer staging system (2009) and similarities between cases and controls were maintained with respect to characteristics like age, sex, or smoking history.

\subsection{Genotype Analysis}

Blood sample (3 - $5 \mathrm{~mL}$ ) from each participant was drawn into an EDTA vial and genomic DNA was extracted following manufacturer's protocol of DNA sure blood mini kit (Genetix Biotech Asia Pvt. Ltd, India). Primerintroduced restriction analysis (PIRA)-polymerase chain reaction (PCR) assay (18) was used to determine the G(-248)A polymorphism (rs4645878) in the promoter region of BAX gene. PIRA-PCR method is usually used where a variant or mutation does not create a new restriction site, it may be possible to perform PCR by using a 
Table 1. Distribution of selected characteristics among the study population.

\begin{tabular}{|c|c|c|}
\hline Variable & NSCLC patients (\%) & Healthy controls (\%) \\
\hline Total No. & 160 & 160 \\
\hline Race & North Indians & North Indians \\
\hline \multicolumn{3}{|l|}{ Gender } \\
\hline Males & $124(77.5)$ & $124(77.5)$ \\
\hline Females & $36(22.5)$ & $36(22.5)$ \\
\hline \multicolumn{3}{|l|}{ Age at diagnosis (years ) } \\
\hline$\leq 45 \mathrm{Y}$ & $32(20.0)$ & $32(20.0)$ \\
\hline$>45 \mathrm{Y}$ & $128(80.0)$ & $128(80.0)$ \\
\hline Mean \pm SD age $(Y)$ & $57.32 \pm 11.9$ (range, 30 - 85 years) & $56.02 \pm 10.6$ (range, 32 - 80 years) \\
\hline \multicolumn{3}{|l|}{ Smoking status } \\
\hline Non smoker & $47(29.4)$ & $47(29.4)$ \\
\hline Smokers & $113(70.6)$ & $113(70.6)$ \\
\hline Current smokers & $48(42.5)$ & $48(42.5)$ \\
\hline Ex-smokers & $65(57.5)$ & $65(57.5)$ \\
\hline \multicolumn{3}{|l|}{ Smoking level (pack year) } \\
\hline Mild $(\leq 10)$ & $18(15.9)$ & $18(15.9)$ \\
\hline Moderate $(\leq 40)$ & $49(43.4)$ & $49(43.4)$ \\
\hline Heavy $(>40)$ & $46(40.7)$ & $46(40.7)$ \\
\hline \multicolumn{3}{|l|}{ Smoking type } \\
\hline Cigarette & $33(29.2)$ & $33(29.2)$ \\
\hline Bidi & $16(14.2)$ & $16(14.2)$ \\
\hline Huka & 27 (23.9) & 27 (23.9) \\
\hline Cigarette + Bidi & $15(13.3)$ & $15(13.3)$ \\
\hline Cigarette + Huka & $22(19.5)$ & $22(19.5)$ \\
\hline \multicolumn{3}{|l|}{ Histological type } \\
\hline Squamous cell carcinoma & 79 (49.4) & \\
\hline Adenocarcinoma & $81(50.6)$ & \\
\hline \multicolumn{3}{|l|}{ TNM stage } \\
\hline Early (I \& II) & $60(37.5)$ & \\
\hline Advanced (III \& IV) & $100(62.5)$ & \\
\hline \multicolumn{3}{|l|}{ Distant metastases } \\
\hline Positive & $42(26.2)$ & \\
\hline Negative & 118 (73.8) & \\
\hline \multicolumn{3}{|l|}{ Histological grades } \\
\hline \multicolumn{3}{|c|}{ Squamous cell carcinoma grades } \\
\hline Grade 1 & $43(54.4)$ & \\
\hline Grade 2 & $22(27.8)$ & \\
\hline Grade 3 & $14(17.7)$ & \\
\hline \multicolumn{3}{|l|}{ Adenocarcinoma grade } \\
\hline Grade 1 & $14(17.3)$ & \\
\hline Grade 2 & $23(27.2)$ & \\
\hline Grade 3 & 45 (55.5) & \\
\hline \multicolumn{3}{|c|}{ Family history of any cancer } \\
\hline Significant & 19 (11.9) & \\
\hline Non significant & $141(88.1)$ & \\
\hline
\end{tabular}


primer containing a mismatch with the target DNA, such that the same base substitution is introduced into both normal and mutated sequences but a restriction site is formed only in the PCR product derived from the variant allele. The method introduces an artificial restriction site into a PCR product by the use of a primer with a single-base mismatch usually introduced near the 3' end of the primer that is close to the nucleotide change of interest. In the present study the mismatch (-2 G-to-C) was present in the sense primer shown in Table 2 as underlined. The mismatch introduced an artificial restriction site for MSP I restriction enzyme in the PCR product which resulted in two band sizes (89 bp +20 bp) when $G$ allele is present at BAX (-248, rs 4645878) position.

PCR was performed in a final volume of $50 \mu \mathrm{L}$ containing 50 ng genomic DNA, $5 \mu \mathrm{L}$ of $10 \times$ polymerase buffer (200 mM Tris-HCl, pH 8.0; $500 \mathrm{mM} \mathrm{KCl),} 3 \mu \mathrm{L}$ of $20 \mathrm{mM} \mathrm{MgCl,} 5 \mu \mathrm{L}$ of $10 \mathrm{mM}$ dNTPs, $0.5 \mu \mathrm{L}$ of $5 \mathrm{U}$ Taq polymerase (Genei, Bangalore) and $0.5 \mu \mathrm{L}$ of $25 \mathrm{pmol} / \mathrm{L}$ of sense and anti-sense primers (Table 2) and the final volume was adjusted by nuclease free $\mathrm{ddH}_{2} \mathrm{O}$. PCR program was started with an initial denaturation at $95^{\circ} \mathrm{C}$ for 5 minutes, followed by 40 cycles of denaturation at $95^{\circ} \mathrm{C}$ for $30 \mathrm{~s}$, annealing at $60^{\circ} \mathrm{C}$ for $45 \mathrm{~s}$, extension at $72^{\circ} \mathrm{C}$ for $45 \mathrm{~s}$, and completed with a final elongation step at $72^{\circ} \mathrm{C}$ for 5 minutes. PCR product of 109 bp (10 $\mu \mathrm{L}$ ) was verified by agarose gel electrophoresis (Figure 1(a)) and the remaining PCR product was then digested by the fast digest restriction enzyme MSPI (Fermentas, USA) at $37^{\circ} \mathrm{C}$ for $15 \mathrm{~min}$. The genotypes were assessed as follows: a single 109 bp fragment for homozygous AA genotype, two fragments of 89 bp and 20 bp for homozygous GG genotype and three fragments of 109 bp, 89 bp and 20 bp for the heterozygous GA genotype (Figure 1(b)). Negative control with $\mathrm{ddH}_{2} \mathrm{O}$ instead of DNA template was included in each PCR run. A blind case/control analysis was performed with approximately more than $10 \%$ random samples were selected for confirmation and the results were $100 \%$ concordant.

\subsection{Sequence Analysis}

The results of the PIRA-PCR analysis were confirmed by sequencing of representative samples for each genotype (Figure 1(c)). PCR products were purified using NucleoSpin PCR Clean-up kit (Macherey-Nagel, Germany) and sequenced on $3730 \times 1$ DNA Analyzer (Life Technologies Corporation, California, USA) according to the manufacturer's instructions. The sequences were compared with BAX data in the GenBank (accession number U17193 for promoter).

\subsection{Statistical Analysis}

Follow up was calculated as per hospital records from the date of diagnosis to the death or till the end of the study and survival analysis was estimated using Kaplan-Meier plots and log-rank (Mantel-Cox) test. Statistical analysis was performed using the Graph Pad Prism 6.0 or SPSS 16.0 software. Assessment of the correlations between genetic carrier status and BAX polymorphism was carried out using the Chi-Squaredor Fisher Exact test. BAX variants and risk of NSCLC were estimated by computing the odds ratios (ORs), risk ratio (RR) and risk difference (RD) with 95\% confidence intervals (CIs). Allele frequencies among cases as well as controls were evaluated by using the Chi-square Hardy-Weinberg equilibrium test. A $p$ value $<0.05$ was considered significant.

\section{Results}

\subsection{Genotype Distribution}

The observed genotype frequencies of BAX (GG, GA and AA) were statistically different among patients and healthy controls (Chi square $=15.1, p=0.0005)$. In addition cases showed higher A allele frequency ( $\mathrm{fA}=0.43$ vs 0.28 ) whereas controls represented with higher $G$ allele frequency ( $\mathrm{fG}=0.72$ vs 0.57 ) Table 3.

Table 2. Conditions of genotyping assay for the BAX (-248 G > A) polymorphism.

\begin{tabular}{|c|c|c|c|c|}
\hline Gene polymorphism & Genotyping & Primers [18] & $\begin{array}{c}\text { Restriction } \\
\text { enzyme }\end{array}$ & Gel band pattern \\
\hline $\begin{array}{c}\text { BAX } \\
(-248 \mathrm{G}>\text { A rs4645878) }\end{array}$ & $\begin{array}{l}\text { PIRA-PCR: mismatch, } \\
\text { sense primer -2 G-to-C }\end{array}$ & $\begin{array}{l}\text { '5-CATTAGAGCTGCGATTGGACCGG-3' (sense) } \\
\text { '5-GCTCCCTCGGGAGGTTTGGT-3' (anti-sense) }\end{array}$ & Msp I & $\begin{array}{c}\text { A allele: } 109 \mathrm{bp} \\
\text { G allele: } 89 \mathrm{bp}+20 \mathrm{bp}\end{array}$ \\
\hline
\end{tabular}




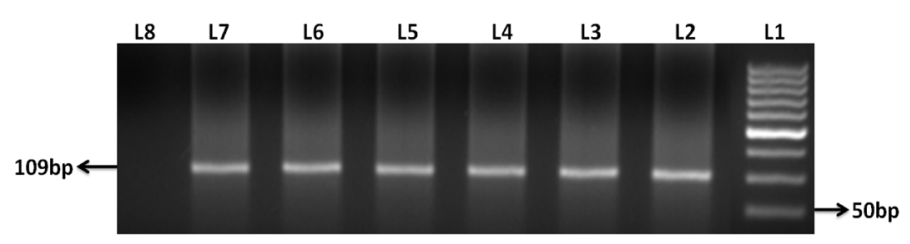

(a)

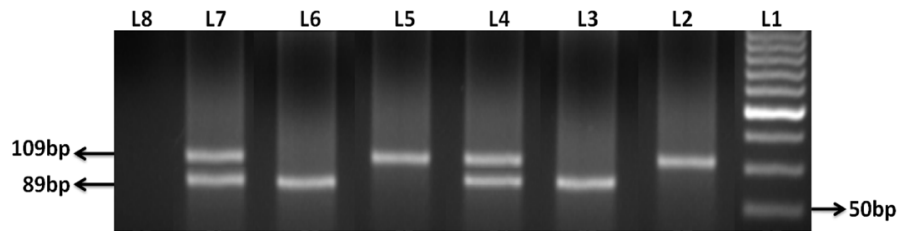

(b)
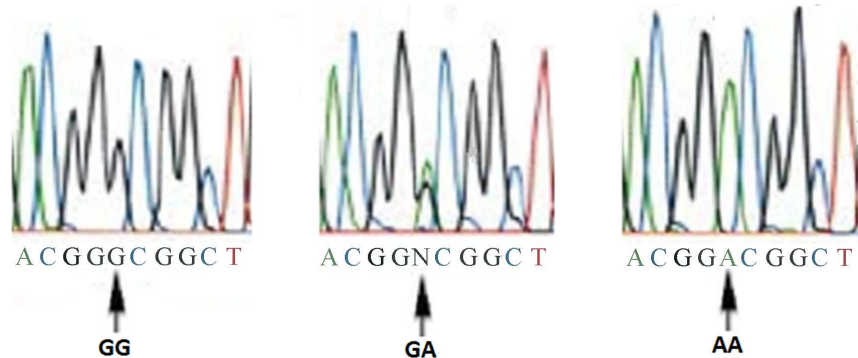

(c)

Figure 1. PIRA-PCR analysis and sequencing of PCR products: (a) PCR amplification of BAX (-248 G > A) showing band size of 109 bp (L2-L7) (b) MSPI restriction digestion of PCR product with BAX (-248 $\mathrm{G}>\mathrm{A}$ ) polymorphic sites, L2, L5-homozygous AA genotype, L3, L6homozygous GG genotype, L4, L7-heterozygous GA genotype and L8negative control. ${ }^{*} 20 \mathrm{bp}$ fragment not visible due to over run. (c) Sequence of the BAX promoter region showing different genotypes at -248 position indicated with the arrows.

Table 3. Genotype frequencies of BAX (-248 G/A) among NSCLC cases and controls.

\begin{tabular}{|cccccccc}
\hline Genotype & $\begin{array}{c}\text { GG } \\
\text { genotype (\%) }\end{array}$ & $\begin{array}{c}\text { GA } \\
\text { genotype (\%) }\end{array}$ & $\begin{array}{c}\text { AA } \\
\text { genotype (\%) }\end{array}$ & $\begin{array}{c}\text { G allele } \\
\text { frequency }\end{array}$ & $\begin{array}{c}\text { A allele } \\
\text { frequency }\end{array}$ & Chi-square & $\boldsymbol{p}$ value \\
\hline Patients $(\mathrm{n}=160)$ & $70(43.8)$ & $43(26.8)$ & $47(29.4)$ & 0.57 & 0.43 & 15.1 & 0.0005 \\
Controls $(\mathrm{n}=160)$ & $90(56.2)$ & $51(31.9)$ & $19(11.9)$ & 0.72 & 0.28 & & \\
\hline
\end{tabular}

\subsection{BAX (-248 G/A) Polymorphism and Risk of NSCLC}

A multivariate analysis based on logistic regression like odds ratio, risk ratio and risk difference with $95 \%$ confidence intervals were calculated for each group to estimate the association between the BAX (-248 G/A) genotypes and risk of NSCLC in Indian patients (Table 4). It was found that an increased risk of NSCLC was associated with the BAX (A) allele in an allele dosage-dependent manner. Compared to the GG genotype, odds ratio, risk ratio and risk difference for the heterozygous GA and homozygous AA genotypes were OR = $1.08(0.65-$ 1.80) $\mathrm{RR}=1.04(0.82-1.30) \mathrm{RD}=1.9(-10.8-14.7)$ and $\mathrm{OR}=3.18(1.71-5.89) \mathrm{RR}=1.95(1.31-2.92) \mathrm{RD}=$ 27.4 (14.1 - 40.8) respectively, suggesting a possible dominant of this polymorphism with 3.2 fold increased risk associated with homozygous AA genotype. Upon comparison with the subtypes of NSCLC significantly increased risks were observed in squamous-cell carcinoma patients, OR = 5.26 (2.6 - 10.8) RR = 1.98 (1.4 - 2.9$)$, and $\mathrm{RD}=38.1$ (22.5 - 53.8) Table 5. The increased risk associated with the BAX polymorphism appeared to be more pronounced in male cases and who were >45 years at diagnosis (OR 4.3 (2.09 - 8.91) and 5.4 (2.5 - 11.8 respectively) for the AA genotype (Table 5). 
Table 4. Risk of NSCLC associated with the BAX G(-248)A genotypes.

\begin{tabular}{ccccccc}
\hline Genotypes & Control $(\mathbf{n}=\mathbf{1 6 0})$ & Cases $(\mathbf{n}=\mathbf{1 6 0})$ & $\left.\mathbf{O R}^{*} \mathbf{( 9 5 \%} \mathbf{C I}\right)$ & $\mathbf{R R}^{\#}$ & $\mathbf{R D}^{\wedge}$ & $\boldsymbol{p}$ value \\
\hline GG (ref) & 90 & 70 & 1 & 1 & & \\
AA & 19 & 47 & $3.18(1.71-5.89)$ & $1.95(1.31-2.92)$ & $27.4(14.1-40.8)$ & 0.0001 \\
GA & 51 & 43 & $1.08(0.65-1.80)$ & $1.04(0.82-1.30)$ & $1.9(-10.7-14.7)$ & 0.75 \\
GA + AA & 70 & 90 & $1.65(1.06-2.57)$ & $1.28(1.09-1.60)$ & $12.5(1.63-23.4)$ & 0.02 \\
\hline
\end{tabular}

*OR: Odd ratio; ${ }^{*}$ RR: Risk ratio; ${ }^{\wedge} \mathrm{RD}$ : Risk difference.

Table 5. Histological prospective of NSCLC risk associated with the BAX G (-248)A genotypes.

\begin{tabular}{cccc}
\hline Genotypes & GG $($ ref $)$ & AA & GA \\
\hline Control $(\mathrm{n}=160)$ & 90 & 19 & 51 \\
Adenocarcinoma $(\mathrm{n}=81)$ & 43 & 17 & 21 \\
Odd ratio (95\% CI) & 1.0 & $1.9(0.90-4.0), p=0.098$ & $0.86(0.5-1.6), p=0.64$ \\
Squamous cell carcinoma ( $\mathrm{n}=79)$ & 27 & 30 & 22 \\
Odd ratio (95\% CI) & 1.0 & $5.26(2.6-10.8), p=0.0000$ & $1.44(0.74-2.8), p=0.27$ \\
\hline
\end{tabular}

\subsection{BAX G(-248)A Genotypes and Clinical Characteristics}

Among the lung cancer patients, 81 (50.6\%) were diagnosed with adenocarcinoma and 79 (49.4\%) with squamous-cell carcinoma. Majority of the cases were in advanced TNM stage $100(62.5 \%)$ including more than 26\% of patients with metastasis to distant organs. Grade 1 SCC 43 (54.4\%) and grade 3 differentiated ADC 45 $(55.5 \%)$ represented a major portion in histological grade of NSCLC cases.

Clinicopathological characteristics including histological type $(p=0.02)$, TNM Stage $(p 0.03)$ and first degree family history of any cancer $(p=0.05)$ showed statistically significant associations with respect to BAX G(-248)A genotypes. SCC patients represented higher A allele frequency (0.52 vs 0.34 ) whereas higher $G$ allele frequency was observed in ADC patients (0.66 vs 0.48). In addition higher prevalence of $f(A)$ was among cases with advanced stage ( 0.49 vs 0.33 ) as well as in cases with metastasis to distant organs ( 0.52 vs 0.39 ) like brain, bone or adrenal etc. Cytological differentiation among ADC as well as SCC showed a continuous increasing trend of BAX A allele frequency from grade 1 to grade 3 differentiations. In relation to parameters like age and gender the BAX promoter polymorphism doesn't presented any significant correlation, however, males and patients of $>45$ years showed higher $\mathrm{f}(\mathrm{A})$ allele (Table 6 ).

\subsection{Gene-Smoking Interaction}

Healthy controls with similar smoking history as those of patients were included in the study in order to find the genetic susceptibility and risk of NSCLC in relation to BAX promoter polymorphism. Smokers constitute more than 70 percent, wherein bidi (61.3\%) and huka (62.3\%) were the major smoking source and about $57 \%$ had left smoking from more than 6 months among both cases as well as controls (Table 1). We observed that although an increased risk of NSCLC cancer was associated with BAX AA genotype in both smokers and nonsmokers, the OR for the AA genotype in smokers OR $4.3(2.04-9.17, p=0.0000)$ was significantly higher than those of nonsmokers OR $1.5(0.49-4.58, p=0.48)$. Moreover, when the risk associated with the BAX polymorphism was further evaluated within the strata of pack-years smoked, risk of development of NSCLC was increasing as the number of pack-years increases (Mild; OR 1.5, Moderate; OR 5.5 and Heavy; OR 7.2). In addition interaction between susceptible genotypes and source of smoking was mostly evident among cigarette (OR 6.7, CI: 1.6 28.9) and huka smokers (OR 6.5, CI: 1.1 - 36.6) (Table 7).

\subsection{BAX (-248 G/A) Genotypes and Clinical Outcome of NSCLC Patients}

Survival analyses were based on 160 NSCLC patients with mean follow-up time of 11.95 months (median 10.50; range, 0.5 - 127.5 months) for the overall survival. Out of 160 NSCLC patients, 87 (54.4\%) died with mean 
Table 6. BAX (-248 G/A) polymorphism with different clinical characteristics of NSCLC patients.

\begin{tabular}{|c|c|c|c|c|c|c|}
\hline Variables & GG genotype (\%) & GA genotype (\%) & AA genotype (\%) & $\mathrm{G}$ allele frequency & A allele frequency & $p$ value \\
\hline \multicolumn{7}{|l|}{ Gender } \\
\hline Males & $50(40.3)$ & $35(28.2)$ & 39 (31.5) & 0.54 & 0.46 & 0.26 \\
\hline Females & $20(55.6)$ & $8(22.2)$ & $8(22.2)$ & 0.67 & 0.33 & \\
\hline \multicolumn{7}{|l|}{ Age at diagnosis (years) } \\
\hline$\leq 45 \mathrm{Y}$ & $16(50.0)$ & 7 (21.9) & $9(28.1)$ & 0.61 & 0.39 & 0.68 \\
\hline$>45 \mathrm{Y}$ & $54(42.2)$ & $36(28.1)$ & 38 (29.7) & 0.56 & 0.44 & \\
\hline \multicolumn{7}{|l|}{ Histological type } \\
\hline Squamous cell carcinoma & $27(34.2)$ & $22(27.8)$ & $30(38.0)$ & 0.48 & 0.52 & 0.02 \\
\hline Adenocarcinoma & $43(53.1)$ & $21(25.9)$ & $17(21.0)$ & 0.66 & 0.34 & \\
\hline \multicolumn{7}{|l|}{ TNM stage } \\
\hline Early stage (I \& II) & $34(56.6)$ & $13(21.7)$ & $13(21.7)$ & 0.68 & 0.33 & 0.03 \\
\hline Advanced stage (III \& IV) & $36(36.0)$ & $30(30.0)$ & $34(34.0)$ & 0.51 & 0.49 & \\
\hline \multicolumn{7}{|l|}{ Distant metastases } \\
\hline Positive & 15 (35.7) & $10(23.8)$ & $17(40.5)$ & 0.48 & 0.52 & 0.14 \\
\hline Negative & $55(46.6)$ & $33(28.0)$ & $30(25.4)$ & 0.61 & 0.39 & \\
\hline \multicolumn{7}{|c|}{ Squamous cell carcinoma grades } \\
\hline Grade 1 & 17 (39.5) & $11(25.6)$ & $15(34.9)$ & 0.52 & 0.48 & 0.15 \\
\hline Grade 2 & $7(31.8)$ & $9(40.9)$ & $6(27.3)$ & 0.52 & 0.48 & \\
\hline Grade 3 & $3(21.4)$ & $2(14.3)$ & $9(64.3)$ & 0.29 & 0.71 & \\
\hline \multicolumn{7}{|l|}{ Adenocarcinoma grades } \\
\hline Grade 1 & $11(78.6)$ & $1(7.1)$ & $2(14.3)$ & 0.82 & 0.18 & 0.18 \\
\hline Grade 2 & $12(54.5)$ & $7(31.8)$ & $3(13.6)$ & 0.70 & 0.30 & \\
\hline Grade 3 & $20(44.4)$ & $13(28.9)$ & $12(26.7)$ & 0.59 & 0.41 & \\
\hline \multicolumn{7}{|c|}{ Family history of any cancer } \\
\hline Yes & $13(68.4)$ & $3(15.8)$ & $3(15.8)$ & 0.76 & 0.24 & 0.05 \\
\hline No & $57(40.4)$ & $40(28.4)$ & $44(31.2)$ & 0.55 & 0.45 & \\
\hline
\end{tabular}

follow up time of 10.46 months ( median 10.00; range, 0.5 - 40.0 months) and for the patients who survived the follow up period (censored patients), the follow up time was 14.24 months (median 13.00; range, 0.5 - 127.5 months). Patients homozygous for A allele exhibited a significant poor overall survival $(p<0.0001)$ Figure 2(a), Figure 2(b). Median survival time for patients with BAX (-248) GG, GA, GA + AA and AA genotype were 30.0, 11.0, 9.0 and 6.0 months respectively. Significant poor overall survival was alsoobserved in patients presented A allele homology with ADC $(p<0.0001)$ or SCC $(p<0.0001)$ histology (Figure 2(c), Figure 2(d)) as well as with early $(p<0.0001)$ or advanced $(p<0.0001)$ TNM stage (Figure 2(e), Figure 2(f)). In addition patients of ADC and advanced stage with AA genotype showed lower median survival time than SCC and Early stage NSCLC patients (Median 3.0 and 5.0 vs 8.0 and 9.0 months respectively).

\section{Discussion}

Low expression of BAX has been found to be associated with poor prognosis and reduced chemotherapy response in NSCLC patients especially with non-squamous histology [19] [20]. BAX transcription is regulated by p53 protein possessing a potent transcriptional activation domain at its amino-terminus linked to a central core domain that mediates sequence-specific direct DNA binding to the TP53-binding element in the promoter of 
Table 7. Risk of NSCLC associated with the BAX G(-248)A polymorphism by potential risk factors in the Indian population.

\begin{tabular}{|c|c|c|c|c|}
\hline Variables & GG controls/cases & AA controls/cases & OR (95\% CI) & $p$ value \\
\hline \multicolumn{5}{|l|}{ Gender } \\
\hline Males & $72 / 50$ & $13 / 39$ & $4.3(2.09-8.91)$ & $<0.0001$ \\
\hline Females & $18 / 20$ & $6 / 8$ & $1.2(0.35-4.13)$ & 0.77 \\
\hline \multicolumn{5}{|c|}{ Age at diagnosis (years) } \\
\hline$\leq 45 \mathrm{Y}$ & $13 / 16$ & 9/9 & $0.8(0.25-2.6)$ & 0.72 \\
\hline$>45 \mathrm{Y}$ & $77 / 54$ & $10 / 38$ & $5.4(2.5-11.8)$ & $<0.0001$ \\
\hline \multicolumn{5}{|l|}{ Smoking status } \\
\hline Non smokers & $24 / 23$ & $7 / 10$ & $1.5(0.49-4.58)$ & 0.48 \\
\hline Smokers & $66 / 47$ & $12 / 37$ & $4.3(2.04-9.17)$ & $<0.0001$ \\
\hline \multicolumn{5}{|c|}{ Smoking level (pack year) } \\
\hline Mild $(\leq 10)$ & $11 / 7$ & $5 / 5$ & $1.5(0.33-7.5)$ & 0.50 \\
\hline Moderate $(\leq 40)$ & $32 / 23$ & $4 / 16$ & $5.5(1.6-18.8)$ & 0.001 \\
\hline Heavy $(>40)$ & $23 / 17$ & $3 / 16$ & $7.2(1.8-28.8)$ & 0.04 \\
\hline \multicolumn{5}{|l|}{ Smoking type } \\
\hline Cigarette & $22 / 12$ & $3 / 11$ & $6.7(1.6-28.9)$ & 0.006 \\
\hline Bidi & $6 / 9$ & $3 / 5$ & $1.1(0.19-6.5)$ & 0.9 \\
\hline Huka & $13 / 10$ & $2 / 10$ & $6.5(1.1-36.6)$ & 0.02 \\
\hline Cigarette + Bidi & $9 / 5$ & $2 / 6$ & $5.4(0.78-37.5)$ & 0.07 \\
\hline Cigarette + Huka & $16 / 11$ & $2 / 5$ & $3.6(0.5-22.2)$ & 0.14 \\
\hline
\end{tabular}

BAX gene and induces BAX expression [21] [22]. A polymorphism in the p53 binding element of BAX gene G(-248)A has been reported to effect the transcription of BAX gene [9] [10]. The present data explored the association of BAX G(-248)A polymorphism in the TP53 binding region with risk and prognosis of non-small cell lung cancer.

Several studies have reported that the SNP located within the untranslated region of the BAX promoter (-248 G/A) was associated with reduced expression of BAX and has been observed significantly lower among BAX (-248)AA genotype than GG genotypes carriers [9] [10]. Clinical studies on lung cancer revealed that low BAX expression was associated with unfavorable clinical outcomes and poor survival [20] [23] [24]. Our study, the first report from Indian population, suggested that homozygous BAX (-248)A allele is strongly associated with the risk of developing NSCLC particularly squamous cell carcinoma with approximately more than 5 fold increase than homozygous BAX (-248)G genotype. BAX (-248)A allele homology was also been found to be an independent prognostic marker of unfavorable clinical outcome with AA genotype at higher risk for death than GG genotype of NSCLC patients.

Histopathological correlations of BAX expression profile and NSCLC in previous studies revealed low BAX expression among patients of squamous cell carcinoma [19] [20] [23]. Present data of BAX polymorphism, shows a close correlation with the previous BAX expression studies, where in frequency of BAX (-248)AA genotype was more in SCC whereas BAX (-248)GG genotype was more among adenocarcinoma patients. A strong correlation between smoking history and low BAX expression was observed in NSCLC patients especially SCC [19] also high BAX (-248)AA frequencies were presented by our smoker patients. In addition increase in BAX (-248)AA frequencies among smokers were concordant with the increase in level of smoke exposure resulting ultimately higher risk of NSCLC among heavy smokers.

In addition we observed as the frequency BAX A allele among patients increases their occurs a transformation of cytological grade from well to poor differentiation in both SCC as well as ADC groups. Poorly differentiated NSCLC tumors showed lower BAX protein levels [25]. Low BAX expression lead to shorter overall survival in 

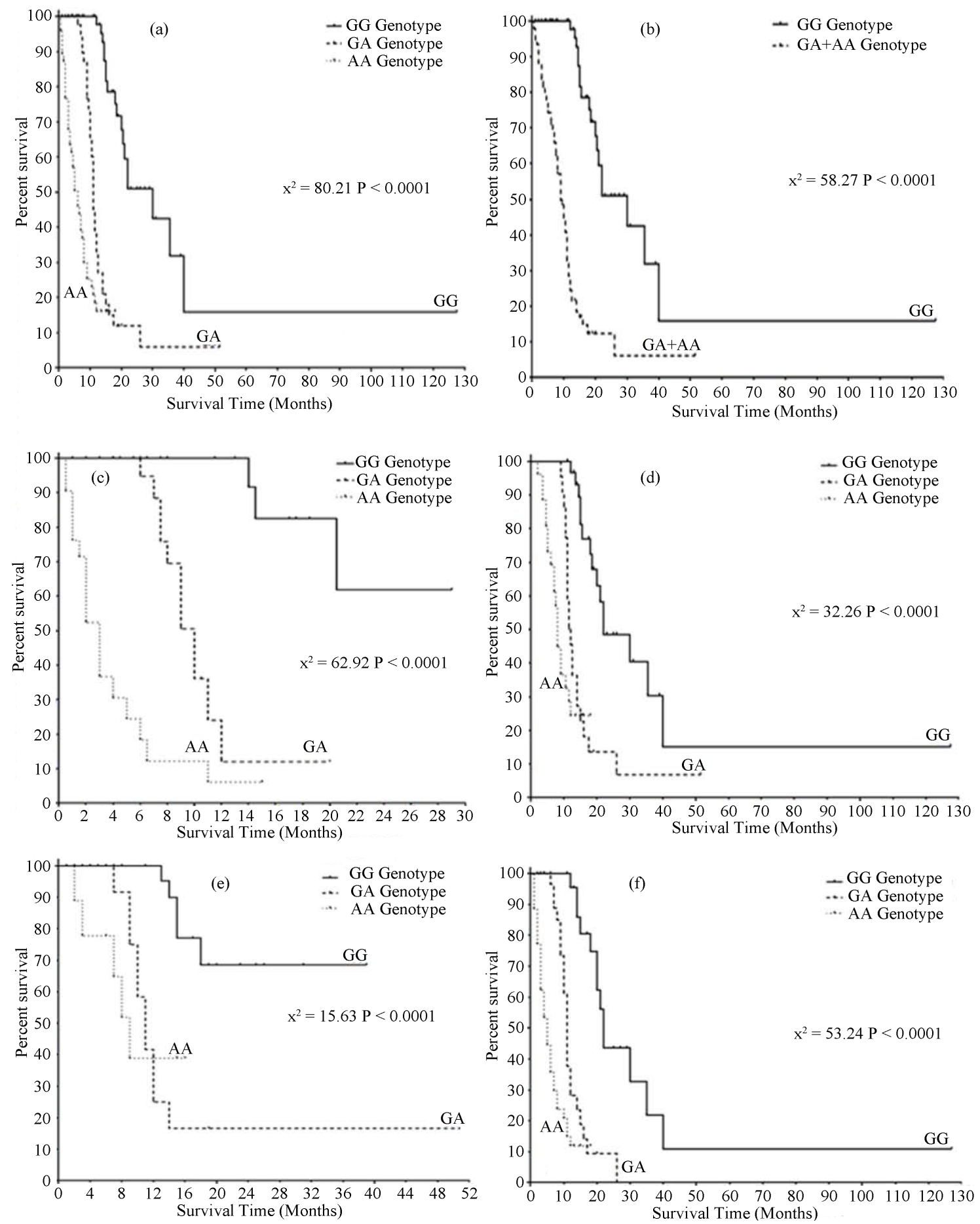

Figure 2. Kaplan-Meier survival analysis of NSCLC patients with respect to BAX G(-248)A polymorphism: (a), (b) Overall survival (c), (d) Survival of ADC and SCC patients, (e), (f) Survival of Early and advanced stage.

various malignancies including NSCLC [9] [19] [26] presently shorter overall survival was significantly associated with BAX (-248)AA genotype among both SCC or ADC as well as Early or Advanced stage patients. The poor outcome of the patients with BAX (-248)AA may be due its weak interaction with TP53 protein altering the transcription of BAX gene.

In relation to the role of BAX in treatment response, it has been found that over expression of BAX sensitizes 
breast cancer MCF-7 cells to cisplatin and etoposide [27], reduced BAX protein was found in cisplatin resistant lung cancer cell lines [28] and increased BAX expression was observed in breast cancer cell lines following treatment with cyclophosphamide [29]. Also BAX was found to be an independent predictive factor of cisplatin response in oral cancer [30]. In case of esophageal cancer poor survival of patients with cisplatin based therapy was associated with low BAX expression [24]. Thus, genotyping ofthe BAX G(-248)A in NSCLC may be helpful to identify candidate patients for novel treatment strategies.

\section{Conclusion}

In conclusion, present study demonstrates that the promoter G(-248) A polymorphism of BAX gene may contribute to the risk of developing non-small cell lung cancer in Indian population. In addition, it may be responsible for adverse clinical outcome and differential treatment response by affecting TP53 regulation of BAX transcription in non-small cell lung cancer patients. Current findings are limited due to small sample size in the strata and results need to validate by large and preferably prospective studies on the BAX promoter polymorphism with its expression profile of NSCLC patients.

\section{Acknowledgements}

The authors specially thank all of the participant's especially non-small cell lung cancer patients who participated in this study.

\section{References}

[1] Parkin, D.M., Bray, F., Ferlay, J. and Pisani, P. (2005) Global Cancer Statistics, 2002. CA: A Cancer Journal for Clinicians, 55, 74-108. http://dx.doi.org/10.3322/canjclin.55.2.74

[2] Dikshit, R., Gupta, P.C., Ramasundarahettige, C., Gajalakshmi, V., Aleksandrowicz, L., Badwe, R., et al. (2012) Cancer Mortality in India: A Nationally Representative Survey. Lancet, 379, 1807-1816. http://dx.doi.org/10.1016/S0140-6736(12)60358-4

[3] Kasper, D.L., Braunwald, E., Hauser, S., Longo, D., Jameson, J.L. and Fauci, A.S. (2005) Neoplasms of the Lung, Harrison's Principles of Internal Medicine. 16th Edition, 506-515.

[4] Levi, F. (1999) Cancer Prevention: Epidemiology and Perspectives. European Journal of Cancer, 35, 1912-1924. http://dx.doi.org/10.1016/S0959-8049(99)00294-4

[5] Schottenfeld, D. and Fraumeni, J.F. (2006) Cancer Epidemiology and Prevention. 3rd Edition, 638-658. http://dx.doi.org/10.1093/acprof:oso/9780195149616.001.0001

[6] Salgia, R. and Skarin, A.T. (1998) Molecular Abnormalities in Lung Cancer. Journal of Clinical Oncology, 16, 12071217.

[7] Thompson, C.B. (1995) Apoptosis in the Pathogenesis and Treatment of Disease. Science, 267, 1456-1462. http://dx.doi.org/10.1126/science.7878464

[8] Gross, A., McDonnell, J.M. and Korsmeyer, S.J. (1999) BCL-2 Family Members and the Mitochondria in Apoptosis. Genes Development, 13, 1899-1911. http://dx.doi.org/10.1101/gad.13.15.1899

[9] Starczynski, J., Pepper, C., Pratt, G., Hooper, L., Thomas, A., Milligan, D., et al. (2005) Common Polymorphism G(-248)A in the Promoter Region of the Bax Gene Results in Significantly Shorter Survival in Patients with Chronic Lymphocytic Leukemia Once Treatment Is Initiated. Journal of Clinical Oncology, 23, 1514-1521. http://dx.doi.org/10.1200/JCO.2005.02.192

[10] Ocana, M.G., Valle-Garay, E., Montes, A.H., Meana, A., Carton, J.A., Fierer, J., et al. (2007) Bax Gene G(-248)A Promoter Polymorphism Is Associated with Increased Lifespan of the Neutrophils of Patients with Osteomyelitis. Genetics in Medicine, 9, 249-255. http://dx.doi.org/10.1097/GIM.0b013e318039b23d

[11] Chen, K., Hu, Z., Wang, L.E., Sturgis, E.M., El-Naggar, A.K., Zhang, W. and Wei, Q. (2007) Single-Nucleotide Polymorphisms at the TP53-Binding or Responsive Promoter Regions of BAX and BCL2 Genes and Risk of Squamous Cell Carcinoma of the Head and Neck. Carcinogenesis, 28, 2008-2012. http://dx.doi.org/10.1093/carcin/bgm172

[12] Yu, D.K., Guo, Y.L., Tan, W. and Lin, D.X. (2010) Functional BAX Polymorphism Associated with Lung Cancer Susceptibility. Chinese Journal of Oncology, 32, 324-327.

[13] Fegan, C., Starczynski, J., Pratt, G. and Pepper, C. (2006) The Role of the Bax Gene Polymorphism G(-248)A in Chronic Lymphocytic Leukemia. Leukemia, 20, 1460-1461. http://dx.doi.org/10.1038/sj.leu.2404280

[14] Nuckel, H., Frey, U.H., Sellmann, L., Bau, M., Durig, J., Dührsen, U. and Siffert, W. (2006) Bax Gene G(-248)A Pro- 
moter Polymorphism and Chronic Lymphocytic Leukemia: Lack of Association with Incidence, Disease Stage and Progression-Free Survival. Leukemia, 20, 724.

[15] Moshynska, O., Sankaran, K. and Saxena, A. (2003) Molecular Detection of the G(-248) A BAX Promoter Nucleotide Change in B Cell Chronic Lymphocytic Leukaemia. Molecular Pathology, 56, 205-209. http://dx.doi.org/10.1136/mp.56.4.205

[16] Saxena, A., Moshynska, O., Sankaran, K., Viswanathan, S. and Sheridan, D.P. (2002) Association of a Novel Single Nucleotide Polymorphism, G(-248)A, in the UTR of BAX Gene in Chronic Lymphocytic Leukemia with Disease Progression and Treatment Resistance. Cancer Letters, 187, 199-205. http://dx.doi.org/10.1016/S0304-3835(02)00378-6

[17] Skogsberg, S., Tobin, G., Kröber, A., Kienle, D., Thunberg, U., Aleskog, A., et al. (2006) The G(-248)A Polymorphism in the Promoter Region of the Bax Gene Does Not Correlate with Prognostic Markers or Overall Survival in Chronic Lymphocytic Leukemia. Leukemia, 20, 77-81. http://dx.doi.org/10.1038/sj.leu.2404030

[18] Hu, Z.B., Li, C.Y., Chen, K.X., Wang, L.E., Sturgis, E.M., Spitz, M.R. and Wei, Q.Y. (2008) Single Nucleotide Polymorphisms in Selected Apoptotic Genes and BPDE-Induced Apoptotic Capacity in Apparently Normal Primary Lymphocytes: A Genotype-Phenotype Correlation Analysis. Journal of Cancer Epidemiology, 2008, Article ID: 147905. http://dx.doi.org/10.1155/2008/147905

[19] Jeong, S.H., Lee, H.W., Han, J.H., Kang, S.Y., Choi, J.H., Jung, Y.M., et al. (2008) Low Expression of Bax Predicts Poor Prognosis in Resected Non-Small Cell Lung Cancer Patients with Non-Squamous Histology. Japanese Journal of Clinical Oncology, 38, 661-669. http://dx.doi.org/10.1093/jjco/hyn089

[20] Porebska, I., Wyrodek, E., Kosacka, M., Adamiak, J., Jankowska, R. and Harłozińska-Szmyrka, A. (2006) Apoptotic Markers p53, Bcl-2 and Bax in Primary Lung Cancer. In Vivo, 20, 599-604.

[21] Thornborrow, E.C., Patel, S., Mastropietro, A.E., Schwartzfarb, E.M. and Manfredi, J.J. (2002) A Conserved Intronic Response Element Mediates Direct p53-Dependent Transcriptional Activation of Both the Human and Murine Bax Genes. Oncogene, 21, 990-999. http://dx.doi.org/10.1038/sj.onc.1205069

[22] Miyashita, T. and Reed, J.C. (1995) Tumor Suppressor p53 Is a Direct Transcriptional Activator of the Human Bax Gene. Cell, 80, 293-299. http://dx.doi.org/10.1016/0092-8674(95)90412-3

[23] Mori, S., Ito, G., Shimokata, K. and Sekido, Y. (2004) p53 Apoptotic Pathway Molecules Are Frequently and Simultaneously Altered in Non small Cell Lung Carcinoma. Cancer, 100, 1673-1682. http://dx.doi.org/10.1002/cncr.20164

[24] Kang, S.Y., Han, J.H., Lee, K.J., Choi, J.H., Park, J.I., Kim, H.I., et al. (2007) Low Expression of Bax Predicts Poor Prognosis in Patients with Locally Advanced Esophageal Cancer Treated with Definitive Chemoradiotherapy. Clinical Cancer Research, 13, 4146-4153. http://dx.doi.org/10.1158/1078-0432.CCR-06-3063

[25] Milas, I., Komaki, R., Hachiya, T., Bubb, R.S., Ro, J.Y., Langford, L., et al. (2003) Epidermal Growth Factor Receptor, Cyclooxygenase-2, and BAX Expression in the Primary Non-Small Cell Lung Cancer and Brain Metastases. Clinical Cancer Research, 9, 1070-1076.

[26] Gessner, C., Liebers, U., Kuhn, H., Stiehl, P., Witt, C., Schauer, J. and Wolff, G. (2002) BAX and p16 $6^{\mathrm{INK} 4 \mathrm{~A}}$ Are Independent Positive Prognostic Markers for Advanced Tumour Stage of Nonsmall Cell Lung Cancer. European Respiratory Journal, 19, 134-140. http://dx.doi.org/10.1183/09031936.02.00219402

[27] Sakakura, C., Sweeney, E.A., Shirahama, T., Igarashi, Y., Hakomori, S., Tsujimoto, H., et al. (1997) Over Expression of Bax Sensitizes Breast Cancer Mcf-7 Cells to Cisplatin and Etoposide. Surgery Today, 27, 676-679. http://dx.doi.org/10.1007/BF02388231

[28] Biagosch, J., Huber, R.M. and Bergner, A. (2010) Reduced Expression of BAX in Small Cell Lung Cancer Cells Is Not Sufficient to Induce Cisplatin-Resistance. European Journal of Medical Research, 15, 448-451. http://dx.doi.org/10.1186/2047-783X-15-10-448

[29] Gibson, L.F., Fortney, J., Magro, G., Ericson, S.G., Lynch, J.P. and Landreth, K.S. (1999) Regulation of Bax and Bcl-2 Expression in Breast Cancer Cells by Chemotherapy. Breast Cancer Research and Treatment, 55, 107-117.

[30] Tsuji, T., Noguchi, M., Kido, Y., Kubota, H., Takemura, K., Nakamori, K. and Hiratsuka, H. (2007) Predictive Assay of Neoadjuvant Chemotherapy in Management of Oral Cancer. International Journal of Oral and Maxillofacial Surgery, 36, 15-19. http://dx.doi.org/10.1016/j.ijom.2006.10.009 
J. Javid et al.

\section{Abbreviations}

BAX: Bcl2 associated X protein;

SCC: squamous cell carcinoma;

ADC: adenocarcinoma;

NSCLC: non-small cell lung cancer;

PIRA-PCR: primer-introduced restriction analysis PCR. 